\title{
The Sephardim of North Morocco, Zionism and Illegal Emigration to Israel Through the Spanish Cities of Ceuta and Melilla
}

\author{
Maite Ojeda-Mata ${ }^{1}$ (D)
}

Received: 15 August 2018 / Accepted: 10 February 2021 / Published online: 13 June 2021

(C) The Author(s), under exclusive licence to Springer Nature B.V. 2021

\begin{abstract}
This text looks at the fluid intersection in the emergence and development of Zionism and the later Zionist-promoted emigration of Moroccan Jews to Israel from what was the Spanish Protectorate zone in Morocco and the Spanish enclaves of Ceuta and Melilla in the north of Sherifian state. This process has received less attention from scholars than similar events in the French zone. However, it has some particularities that merit specific attention. From the early years of contact between North Moroccan Jews and European Zionism, the strong cultural identity of the Sephardim in the region and the mobilization of a Spanish approach informed by philoSephardism marked an important difference with regard to the French zone in the reception of Zionism and the organization of emigration to Israel. Paradoxically, in the Spanish protectorate, such process resulted in the disappearance of important historic Sephardic centers like Tetouan, Larache, and Ksar-el-Kebir.
\end{abstract}

Keywords Sephardim · Zionism · Philo-Sephardism · Underground emigration · North Morocco

\section{Introduction}

This article investigates the sociopolitical processes that impacted the Jewish populations of North Morocco and, particularly, those living in the Spanish zone of the Protectorate in the twentieth century. The paper explores the relationship between local developments regarding the beginnings, progress, and outcomes of Zionism in the Spanish Protectorate in Morocco and the Spanish cities of Ceuta and Melilla, and the broader regional, national, and international processes. It also illustrates the similarities and important differences regarding the development of Zionism and

Maite Ojeda-Mata

omate@uv.es

1 Department of Sociology and Social Anthropology, Faculty of Social Sciences, Universitat de València, Av. Tarongers, 4b, 46021 Valencia, Spain 
emigration to Israel in the French and Spanish zones in the country. The study shows how cultural identity and language, mostly Sephardic in the northern zone, had an influence on the acceptance and outcomes of Zionism there, as well as the mobilization of cultural-largely imagined and ambivalent-affinities with the Spanish state. Finally, the paper illustrates how, in the framework of the global processes that affected North Moroccan Jews in the twentieth century, local dynamics, personal networks and relationships-both intra- and inter-community-and even personal attitudes, qualities, and commitments were all fundamental in implementing a much broader international project at the local level.

Historical, sociological, and ethnographic studies of the Jews of Morocco during the colonial period generally focus on the French-controlled area and ignore the particularities of the Jews living in the Spanish zone, or mention them only briefly. ${ }^{1}$ This disregard also extended to other subjects related to Spanish colonialism in Morocco, in part due to Spain's weakness as a colonial power in modern times, which contributed to Moroccan colonial history being largely narrated from the perspective of French colonialism (Calderwood 2018, 17). This was also due to an interest in silencing everything related to the former Spanish Protectorate in Morocco during the late Franco period (Campoy-Cubillo 2012, 18). However, despite the fact that Spanish colonialism in Morocco was considered a replica of French colonialism, which is partially true, the specific historical political experiences of France and Spain in the twentieth century require a focus on the particularities and consequences of their respective colonial policies. Spain suffered a devastating Civil War that put an end to the Spanish Second Republic; the Spanish Civil War deeply polarized Spanish society in the Peninsula, its sovereign territories, and its protectorate zone in Morocco, and the winners carried out a harsh and systematic repression of their political opponents. France, on the other hand, was partially occupied by Nazi Germany during World War II, with a puppet government established in the unoccupied zone with its capital in Vichy; the Vichy government applied an anti-Semitic policy with anti-Jewish laws and deportation, which extended to the French colonies and protectorates in North Africa. Moreover, France had been directly involved in the partition of the Ottoman empire, which later led to the creation of the State of Israel, while Spain lacked a political presence or influence in the Middle East.

An increasing awareness of the particularities of colonialism in the northern zone of Morocco has led to the production of more scholarship on Spanish colonialism in Morocco in general and, to a lesser extent, on the specificities of the North Moroccan Jewries in the Spanish zone and Tangier² (i.e. Serels 1991; López Álvarez

\footnotetext{
1 This is not true of philological and cultural studies, which excited an early interest on the part of Spanish scholars that was later followed in Spain, Israel, the United States, Canada, and other countries by researchers like Paloma Díaz Más, Susana Weich-Shahat, and, more recently, Vanessa Paloma Elbaz (Díaz Más 1986; Weich-Shahak 2008; Paloma Elbaz 2016a, b). For a summary of the early development of Spanish scholarly studies on the Jews of Morocco, see Spanish Bibliography on the Jews of Morocco (Martín Corrales and Ojeda-Mata 2016).

2 Tangier acquired the status of international city in 1923 and was under joint administration by France, Spain, and the UK. The city was a special case in the country. As far back as the nineteenth century, it was the center of foreign diplomacy in Morocco. Under Franco, Spain occupied Tangier in 1940, and the city was not returned to its previous international status until 1945. After 1956, with the independ-
} 
2004; Rohr 2011; Friedman 2011; Martín Corrales 2013a, b; González González 2013; Ojeda-Mata 2014; Marchán Gustems 2014; Moreno 2014, 2020; Cohen and Moreno 2017; Schroeter 2018; Calderwood 2019). Even though these studies are undoubtedly valuable additions to the scant previous existing socio-historical scholarship (i.e. Vilar 1978, 1985, 2000; Leibovici 1984), there are still many aspects that require further attention (Nicosia and Ergene 2018, 6). Likewise, Jewish historical and sociological studies in the Spanish cities of Ceuta and Melilla in northern Morocco still need further consideration despite the growing corpus of scholarship (i.e. Salafranca Ortega 1987, 1995; Riaño López 1998; Ojeda-Mata 2010, 2013; Fernández Díaz 2012; Tarrés 2013; Gómez Barceló 2014).

The study of French-Spanish rivalries regarding the colonization of Morocco also demands further research. Spain had focused its colonial ambitions on North Morocco since the mid-nineteenth century. The 1912 Treaty of Fez made Morocco a protectorate of France, while the Spanish assumed the role of protecting power in a narrow strip in the north as well as the southern Sahara. The northern area under Spanish rule included some of the cities with the highest historic concentration of Sephardic Jews in the country, such as Tetouan, Larache, Ksar-el-Kebir, Chefchaouen, and Asilah. Philo-Sephardism was very strong among members of the Africanist ${ }^{3}$ military and the diplomats in the Ministry of Foreign Affairs. It is against this distinct historical and political background that the Spanish policy of seeking the support of Morocco's Sephardic Jews must be viewed. In fact, unlike French historiography about the Jews of Morocco, one of the earliest topics analyzed in the Spanish case concerned the expulsion of the Jews from Spain and their resettlement in northwest Africa (Martín Corrales and Ojeda-Mata 2016, 109).

Additionally, most of the Sephardim in North Morocco maintained their cultural specificity-language, religion, and cultural traditions-after their expulsion from the Iberian kingdoms in the early modern era, while adapting to and incorporating elements from their new context. ${ }^{4}$ The philo-Sephardic policy was well received

\section{Footnote 2 (continued)}

ence of Morocco, Tangier retained its special transitional situation with regard to the rest of the country for one more year. Therefore, Tangier was a unique case within Morocco. Nevertheless, the geographic proximity of Tangier and Tetouan, Larache, and other cities in North Morocco with important Sephardic minorities, along with personal and business relationships across the border, made it impossible to ignore the influence of the international city in the Spanish zone. Moreover, as in Tetouan, Spanish was the language spoken the most during the colonial years.

3 Spanish "Africanism" is a variant of European Orientalism focused exclusively on Africa and with a more applied and pragmatic approach (Morales Lezcano 1988, 12-18).

4 This was not the case for the Sephardim who settled in Fez and other cities south of the Loukkos River after the expulsion in 1492, who assimilated Moroccan Arabic but did not lose other cultural features, and continued to be called "megorashim" (expelled), as opposed to the "toshabim" (locals, natives). In the north, however, the Sephardic Jews who settled among the kabyles of the Rif Mountains assimilated the Tamazight languages. Therefore, some scholars prefer to use the term "Hispanic-Moroccan Jews" instead of Sephardim (i.e. Israel Garzón 2008; Cohen and Moreno 2017; Cohen 2017) to refer to the population that I call northern Moroccan Sephardim, which is undoubtedly more descriptive and accurate, as the term Sephardim implies other categories as well. However, I feel more comfortable with the term "Iberian-Moroccan Jews," as the concepts "Hispanic" and "Moroccan" are problematic in their own way and require further clarification as, indeed, does "Iberian." For all of these reasons, I have decided 
among part of the Sephardic elite, particularly those whose businesses had ties to Spain or those who were Spanish protégées or had Spanish citizenship. ${ }^{5}$ Spanish cultural policies included both the recovery of the Sephardim's oral traditions and their assimilation into modern Spanish language and culture. ${ }^{6}$ Northern Moroccan Sephardic elites started to incorporate philo-Sephardism into their own construction of their cultural identity as well (Guershon 1996; Rohr 2008, 2011; González González 2013; Ojeda-Mata 2014; Schroeter 2018, 183). At the same time, the Africanists maintained the parallel discourse of Spanish-Muslim brotherhood. Paradoxically, however, old and new forms of prejudice against Muslims and Jews were shared by most of the colonialists, alienating both groups from the colonizers and leading to the search for alternative collective political projects (Mateo Dieste 2003).

The specific subject of Zionism in the northern zone and emigration to Israel is still a very sensitive issue in northern Africa in general and in Morocco in particular (Abécassis and Dirèche 2012, 27). Here, there are also important differences with regard to the characteristics and reception of Zionism in the French zone, as well as the process of Zionist organized migration. While the bulk of the emigration of Jews from Morocco to Israel was planned and carried out from the French zone, the northern zone took over the organization of emigration after the country gained its independence. As a result of the Moroccan ban on emigration to Israel and the closure of the Jewish Agency's Casablanca office in 1956, the Spanish enclaves in North Morocco became the most viable exit route for underground emigration. This hidden process, organized by local cells with very little written documentation, adds a new obstacle to the reconstruction and visibilization of the colonial and postcolonial history of North Morocco and the impact on its Jewish communities.

One of the first scholars to discuss Zionism and emigration to Israel through the Spanish zone was Michael M. Laskier, although his research primarily focuses on developments in Zionism and Jewish emigration to Israel from the French zone, as his main sources came from French and Israeli archives (Laskier 1983, 1985, 1989, 1994). Nonetheless, not much research has been done on Zionism in Morocco in general, or even French Morocco in particular (Cohen 1980; Abitbol 1982; Baïda 2011; Tsur 2012; Bin-Nun 2013, 2014), and Laskier's is probably the most comprehensive study to date. Apart from Laskier, one new key scholarly reference on Zionism and migration from the northern zone of Morocco-mainly Tangier-is the work by Aviad Moreno (Moreno 2014, 2015, 2017, 2020; Cohen and Moreno 2017).

\footnotetext{
Footnote 4 (continued)

to use the term Sephardim in this case. I thank the anonymous reviewers for bringing the need to clarify this and other relevant points in the text to my attention.

5 Beginning in the middle of the nineteenth century, the main colonial powers with interests in Morocco initiated a race to attract the country's elites - particularly the Jews - to their economic and political projects, helping to erode the power of the sultans. The mechanism used was consular protection, which put the protected person under consular jurisdiction rather than the jurisdiction of the makhzan, the Moroccan state administration.

6 The language spoken by the Jewish-Iberian diaspora in Morocco was Haketia, also known as JudeoSpanish or Western Ladino. Haketia is primarily based on medieval Castilian Spanish with components of Maghrebi Arabic and Hebrew (Pinto-abecasis 2017, cxiii).
} 
The main goal of this article (which was made possible thanks to generous funding from the Instituto de Estudios Ceuties) is to bring a social historical process to light from the perspective of social history and historical ethnography, almost as "raw" material, rather than to contribute to theories on nationalism, political movements, or migration studies. I am interested, however, in determining whether philoSephardism was activated during this process, when, by whom, how, and why. I also hope that this paper will constitute a solid beginning for future research on these and other aspects related to Zionism and migration from what was the Spanish Protectorate in North Morocco.

My primary sources are documents held in Spanish archives-which to my knowledge have not been used to date for the study of Zionism and emigration to Israel from the Spanish Protectorate and Ceuta and Melilla-as well as documents from the Central Zionist Archive in Israel. I have complemented the archival sources with a number of interviews in Ceuta with direct or indirect witnesses of the migration process through that city. The archival research turned out to be more complex than expected. Despite the fact that traces of Zionism and Jewish emigration through North Morocco can be found in several Spanish sources, the most important documentation in the Spanish archives is not only fragmented but is still being slowly declassified. The Central Zionist Archive in Israel is available for the consultation of reports regarding Zionist activities in North Morocco. However, as Zionism was not officially allowed in the Spanish Protectorate zone (or the French zone, for that matter) and the smuggling of emigrants via the Moroccan-Spanish border was a risky illegal and underground activity engaged in by local Zionist cells, the archives only contain a partial track record. The attempt to reconstruct the development of Zionism and Zionist-fostered migration is based, then, on spotty documents held in Spanish and Israeli archives, complemented by a very fragmented oral history and some comprehensive memoirs. Like the tip of an iceberg, these findings indicate that there was a small, but established, substrate of active local Zionism in the Spanish zone that made it possible to organize and mobilize Jewish and non-Jewish local contacts in order to smuggle groups of Moroccan Jews through Ceuta and Melilla after the independence of Morocco and the prohibition of migration to Israel. Future research and the discovery of new documents, such as communal records or Moroccan sources, may shed more light on the still unclear aspects of this process.

This paper is organized in three sections: the first looks at the beginnings of local Zionism around the 1900s in the area that would come to be the Spanish Protectorate in 1912, with Tetouan as its capital. It shows the early influences and ambivalent reception-even opposition - to the movement, and the role of Sephardic identity and language in accepting Zionism in the north. Without a previous local network of Zionist activists, it would have been more difficult to articulate and carry out the illegal emigration of Moroccan Jews through the former Spanish zone, Ceuta, and Melilla, after Moroccan independence.

The second section presents the activation of the so-called Aliyah Bet in the northern zone, paying particular attention to the first moves on the part of Israeli agents in the north to find new harbors from which to continue the illegal emigration of Moroccan Jews when it became impossible to use the traditional routes via Casablanca in the south and Tangier in the north. The third section addresses the crucial 
role of the Spanish cities of Ceuta and Melilla in this process, focusing on how the mobilization of local agents, and inter- and intra-community networks, as well as the role-whether passive or active - of the Spanish local and consular authorities, made it possible to use these Spanish cities as exit harbors.

\section{The Sephardim and Zionism in the Spanish Protectorate Zone in Morocco}

Researchers often place the emergence of Zionism in Morocco in the southern part of the country and, in particular, the city of Fez after the creation of the French Protectorate (Cohen 1980; Tsur 2012). However, the communities in northern Morocco also came into early contact with European Zionism and its founder, Theodor Herzl, through the Tetouan rabbi, Yudah Leon Jalfón. ${ }^{7}$ In fact, the first known modern Zionist society in Morocco was established in Tetouan-in his book on the collective memories of former Moroccan Zionist activists, Michel Knafo quotes from a letter sent by Jalfón to Herzl as early as 1900, reporting on the creation of a Zionist society Shivat Sion (Return to Sion) in that city (Knafo 2008, 23)—followed by a second association in Essaouira and a third one in Safi, before the creation of a Zionist society in Fez in 1908. At times this was a result of the encouragement and assistance of European Zionists who visited or settled in Morocco, as was the case in Tetouan. However, by the 1930s many of these societies had little activity or had disappeared (Yehuda 1981 in Laskier 1994, 32-34).

In a newspaper article published in 1912 in Tangier, Jalfón also wrote that he preferred that North Morocco be part of the French protectorate as well. It seems the Tetouan community was divided between those who favored French influence and those who were happy to be under Spanish rule (Guershon 1996, 186). In 1919, Jalfón published another article in the Spanish newspaper El Eco de Tetuán endorsing and praising Zionism. This text by Jalfón is crucial because of its fusion of religious Zionism with political Zionism. The rabbi defined Sion (Palestine) as the birthplace of the Jewish nation and Zionism as "the idea of a free people living in their free homeland." To the question: "Why are we going to Sion?" he replied: "We are going to become a free nation, and make it a model country where freedom will prevail with the highest degree of justice, where those who cultivate knowledge will find peace of mind for its most perfect development and every idea of progress will find, as it were, a land full of culture and morality'. ${ }^{\text {. }}$

\footnotetext{
7 According to Laskier, an important segment of early Zionist sympathizers comprised the graduates of the Alliance Israélite Universelle (AIU) schools, in addition to rabbis. However, the AIU leadership opposed the idea of emigration to Palestine and the creation of a Jewish state, a position adopted by most of the directors of the AIU schools in North Africa, but not the teachers. After World War II, however, the AIU embraced a more pragmatic and tolerant position regarding Zionism and the emigration of North African Jews to Palestine/Israel (Laskier 1994, 34, 46-53).

${ }^{8}$ Quoted in Botbol Hachuel, La comunidad judía de Tetuán y el sionismo (1997, 6), author's translation (unless otherwise stated, all translations are the author's).
} 
With this powerful advocate, Zionist associations multiplied, despite the express Spanish prohibition of any association except for charities established in 1924 (Martín Corrales 2013a). Jalfón was an essential pillar of support for Palestinian Zionism in the Spanish Protectorate, as well as for Spanish-American Sephardic communities such as the Argentinian, as many Sephardim from Argentina had been born in northern Morocco. ${ }^{9}$ However, the delegate sent by the Zionist Executive of Palestine in 1928 to collect contributions for the Zionist cause through the Keren Hayesod foundation fund claimed to have encountered enormous problems raising funds. The Tetouan community was divided into several factions, and those not on Jalfón's side were reluctant to contribute. In Tangier, it was also challenging to solicit aid for the Zionist project in Palestine, both because of the change in community president and the disinterest and indifference of its elites. The Zionist Executive delegate believed that a letter from Arthur Balfour could help garner support for the Palestinian project, as some of the well-off members of the community were naturalized British citizens. Neither did the banker Abraham Bengualid contribute to the Zionist venture, although he did make a donation to Keren Hayesod. Bengualid was a descendant of Isaac Bengualid, the great nineteenth-century rabbi and tzaddik of Tetouan. Abraham Bengualid was also receptive to the idea of donating his valuable family library to the Hebrew University of Jerusalem. ${ }^{10}$

According to the Palestinian emissary Ariel Bension, of the Jewish Foundation Fund, who arrived in Morocco in the early 1920s (Laskier 1994, 34), among the Jewish communities in northern Morocco, the main reasons for resistance to Zionism were that they saw it as an irreligious movement and believed that it did not take the interests of the Sephardim into account. Bension had better luck with the Spanish Protectorate authorities, High Commissioner General Sanjurjo and Plenipotentiary Minister Diego Saavedra. Sanjurjo and Saavedra claimed that their interest and support for the Zionist cause was due to Spain's link with the Sephardic Jews. The delegate from Palestine also suggested sending various Zionist journals and literary and religious publications to several personalities in northern Morocco, both Jews and the Spanish authorities. These publications and communications were to be preferably in Spanish or, failing that, French, which he said were the languages known by the members of the community. He added that the only person who understood Modern Hebrew was Rabbi Yudah León Jalfón, and that it was better not to send press reports and correspondence in English because of a general ignorance of that language. This situation contrasts with the linguistic preferences of the first Zionists in the communities of southern Morocco, who had shown their predilection for Hebrew to combat assimilation into what they understood to be "foreign languages": Arabic, but, above all, French (Knafo 2008, 25). In addition to Jalfón, Bension also suggested sending Zionist correspondence to northern Moroccan residents

\footnotetext{
9 María Ángeles Cohen, Recordar, resistir, apostar: conversaciones con judíos hispano-marroquíes en Israel y Argentina. PhD. Diss. Universidad Autónoma de Madrid/The Hebrew University of Jerusalem $2017,310$.

10 "Weekly Report of A. Bension to the Keren Hayesod-Palestine Foundation Fund in Jerusalem," Ceuta, 11 January 1928 (Central Zionist Archives, CZA, S25-625-3).
} 
Jaime Vidal Israel and Alo Israel. Additionally, he indicated that publicity should be printed in the Jewish press-such as the Jewish Chronicle-about the excellent reception of Zionism by the Spanish authorities in the protectorate and that a copy be sent to these authorities. The emissary also gave various names of Jewish bankers from northern Morocco who might be interested in making investments and doing business in Palestine, such as Isaac Toledano, Abraham Israel, Isaac Cohen, and Salomon Garzón. ${ }^{11}$

Regarding the existence or possibility of creating pioneer youth Zionist organizations, Bension affirmed that they did not exist and that he did not consider their creation feasible. Concerning sending future delegates, he insisted on four conditions for them to succeed: that they knew the Spanish language, that they were acquainted with North Morocco, that they were respectful of religion, and that they were Sephardic. In a previous report, he explained that during a conference on Zionism in Tetouan, a propaganda publication from Bene Kedem, a Zionist organization in Argentina, was distributed to the audience. According to Bension, this publication was very well received among the several hundred attendees because it was in Spanish. $^{12}$

Tetouan's Zionism also influenced the Jewish communities in the former Spanish military outposts of Ceuta and Melilla, as many of the members were originally from Tetouan. In Ceuta, contacts with Zionism were documented as early as 1919. As with Yudah Leon Jalfón in Tetouan and other cities in Morocco, in Ceuta the community rabbi was responsible for the first contacts with European political Zionism. In 1921, the Zionist headquarters in London received a telegram about the success of a conference and the collection of money-100,000 francs-from some twenty families from the "Israelite colony" of Ceuta. "Barchilon President of Shaare Sion," the leader of an Orthodox Sephardic congregation, signed the telegram. ${ }^{13}$ The Jewish community of Ceuta would continue to contribute to the Zionist cause in Palestine through Keren Hayesod in the following years. ${ }^{14}$

In those early years, Zionism in Spain was also connected to the figure of Ignacio Bauer Landauer. Ignacio Bauer was an influential leader of the Jewish community of Madrid whose family had represented the Rothschild house in Spain since the mid-nineteenth century. In 1920, when the Hispanic Zionist Federation was created, its president was Bauer; in 1922, this federation changed its name to the Iberian-Moroccan Zionist Federation. It was not unusual to find figures

\footnotetext{
11 "Weekly Report of A. Bension to the Keren Hayesod-Palestine Foundation Fund in Jerusalem," Ceuta, 11 January 1928; "Report on public meeting held on Progress of Palestine," Tetouan, 3 December 1927 (CZA, S25-625-3).

12 "Weekly Report of A. Bension to the Keren Hayesod-Palestine Foundation Fund in Jerusalem," Ceuta, 11 January 1928; "Report on public meeting held on Progress of Palestine," Tetouan, 3 December 1927 (CZA, S25-625-3). See also Brodsky, Sephardi, Jewish, Argentine: Creating community and national identity, 1880-1960 (2016, 123-25, 234).

13 "Communication from Ceuta's rabbi to the Zionist Organization," Ceuta, 6 September 1919 (CZA, Z4-42499); "Telegram No. 1825 from Ceuta to the Zioniburó President Weitzmann in London," Ceuta, 11 August 1921 (CZA, Z4-42499).

14 "Letter from Leo Herrmann to the Palestine Zionist Executive," Jerusalem, 26 January 1928 (CZA, S25-625-3).
} 
who simultaneously participated in Hispanist movements, such as philo-Sephardism, and Zionism. Bauer also financed the Hispanist journal, Revista de la Raza, through its publisher, Compañía Ibero-Americana de Publicaciones, which he had founded together with the Africanist Manuel L. Ortega. The Iberian-Moroccan Zionist Federation inserted a regular bulletin in this publication. During the Second Spanish Republic, Bauer moved to Ceuta, as his family businesses had been ruined by the economic crisis that followed the stock market crash of 1929. In Ceuta, he temporarily occupied a seat in the Hispano-Moroccan Institute until the outbreak of the Civil War. Bauer was also a recognized monarchist. Disappointed by the political changes in Spain during the Republic, he turned to Zionism and the Jewish communities in those years. He also wrote some of his publications in Ceuta during that period, such as the text in French that he presented in 1938 to the International Congress of Geography of Amsterdam, "Les israélites dans le Rif" (Bauer 1938; Álvarez Chillida 2002; Gómez Barceló 2012).

However, during the years of the Republic, what stood out more than Zionist activism was the political participation of many Jews living in the Spanish Protectorate and in cities under Spanish sovereignty in the local Republican political parties and Freemason lodges. Although several prominent Jews from northern Morocco helped the insurgents during the Spanish Civil War, many others suffered the persecution that hovered over all those who opposed the new regime from different political positions. Indeed, documented cases of reprisals against Sephardic Jews by the pro-Franco movement are numerous in Melilla, Ceuta and the Peninsula, the Spanish Protectorate, and Tangier (Sánchez Montoya 2004; Moga Romero 2005; Ojeda-Mata 2010, 2012; Fernández Díaz 2012; Martín Corrales 2013b).

The end of the Second World War, the creation of the State of Israel, the increasing tensions between Muslims and Jews in Morocco that led to the violent attacks on the Jewish communities of Oujda and Djérada in the northeast, and the French ban on emigration to Israel forced Israeli Zionist activity in the country to reorganize and intensify, while continuing to focus on the French Protectorate. The Mossad was in charge of these early operations, and emphasis was placed on youth migration (Laskier 1994, 92-101, 138-39). According to Arieh Azoulay, the focus on the French zone was due to the fact that the language spoken by most Jews in the Spanish Protectorate was still a sort of Hispanicized Haketia, despite the efforts of the Alliance Israelite schools (AIU) to spread French. Most Israeli emissaries had an Ashkenazi background and did not know Spanish. Nonetheless, Israeli emissaries moved around the northern zone, although less regularly than in the south, circulating Zionist texts and propaganda in both areas. In fact, when the Zionists and French authorities in Morocco were holding negotiations on the quotas for the emigration of Moroccan Jews to Israel in 1949, one of the Israeli emissaries in charge of these negotiations, Jacob Gerszuni, also visited the northern zone. The Jewish Agency requested a visa for Gerszuni from the Spanish authorities to go to Tetouan, presenting him as a "journalist." It is likely, as Laskier observed in the French zone, 
that Gerszuni was, in fact, working for the Mossad, but under the guise of a Jewish Agency worker (Laskier 1994, 110-12). ${ }^{15}$

The presence of Moroccan Jewish youth movements in the north also increased in these years, particularly in Tangier, both among scout and Zionist pioneer groups. The largest Jewish youth organizations in Tangier were the scouts Eclaireurs Israélites de France, and the pioneer organizations Habonim and Dror, although there are traces of Hashomer Hatzair activity in that city as well. These groups' activities were aimed at preparing young people for emigration to Israel, although Israeli agents cautioned that most of Morocco's Jewish urban youth neither belonged to youth movements nor had a clear idea about Zionism (Laskier 1994, 148-49). In addition, Casablanca had received many Jews from the north who were trying to escape from the implacable Franco purges. Since Casablanca was the city where Zionist actions and the youth and pioneer movements were centralized, it is not surprising to find Jews from Tangier, Tetouan, Larache, and even Ceuta and Melilla participating in the scout and Zionist movements in the French zone. Many of the members of these movements would later emigrate to Israel (Azoulay 2014, 131, 227-54).

After the creation of the State of Israel, official relations between Spain and the young state were nonexistent. In fact, Israel was one of the countries that most opposed the international recognition of Franco, due to his alliance with Hitler and his expressed desire for Nazism to triumph. Meanwhile, since 1946, Spain had oriented its foreign policy not only towards Ibero-American countries, but also to the recently independent Arab nations opposed to the creation of a Jewish state in Palestine. In addition, Spanish public opinion was bombarded with media propaganda designed to stimulate anti-British and anti-Zionist sentiments, especially from media outlets closest to the regime (José Antonio Lisbona 2002, 29-37).

Nevertheless, Spain and Israel maintained unofficial contact beginning as early as 1948, with some of these early contacts being made discreetly in Tangier. Not yet a member of the United Nations in 1947-1948, Franco's Spain did not take sides over the partition of Palestine into an Arab state and a Jewish state, but did express concern about the future of Christian sanctuaries in the Holy Land in the case that conflict broke out (José Antonio Lisbona 2000, 29). After making contact with the Arab countries, which responded favorably to the Spanish request, Franco's Minister of Foreign Affairs, Alberto Martín-Artajo, ordered the Consul General of Spain in Tangier, Cristóbal del Castillo, to consult the local Jewish community about the best way to approach Israel regarding the question. The Sephardic writer and Tangier representative of the Jewish National Council of Palestine, Carlos Nesry, was to be contacted “...with all discretion [...] to find out if it would be possible for Spain to make a similar approach to the Jewish authorities in New York without raising the

\footnotetext{
15 "Telegram from the Ministry of Foreign Affairs of Spain on the visa to Tetouan for the journalist from the Jewish Agency Jacob Gerszuni," Madrid, 2 September 1949 (General Consulate in Tangier Archive, CGE Tangier, Israelite Policy, 1948-1955).
} 
objections of the various Jewish groups or inciting Jewish demonstrations against the Arabs, which this Ministry is especially interested in avoiding."16

With the collaboration of Nesry, the Franco government's consular authorities in Tangier reached out to several members of the Jewish community there known for their sympathies towards Spain. Among these was Jacques Pinto, delegate to the World Jewish Congress that was going to be held in the United States in 1948. The consul in Tangier wrote to the Spanish Foreign Minister indicating that he and Nesry agreed that Pinto should approach the government of Israel during the congress. The consul argued that Pinto had direct communication with the authorities in the new country. Nesry agreed that the best option was to reach out to the representatives of the Jewish state in New York, an opinion shared by Jaime Nahón, another influential member of the Tangier Jewish community and, according to the Spanish authorities, both pro-Spanish and pro-Franco. After meeting with the Spanish consul in Tangier, Nahón informed Pinto that the Spanish authorities were going to request that he intercede with Israel during his stay in New York. Jacques Pinto agreed, provided that the Spanish Embassy in Washington demanded that he do this. Nesry also considered that it would be good for the Spanish press to report that the Franco government was making "sentimental" and "informal" approaches to the Arab League and Israel about the need to respect Christian sanctuaries in Palestine in case of war. ${ }^{17}$

Finally, Franco's government also commissioned Nesry to make a direct petition to the government of Israel regarding the protection of the sacred Christian sites in the Holy Land. In his first telegram to the Israeli Minister of Foreign Affairs, Nesry explained that the Spanish government had chosen him to intercede regarding the Holy Places of Jerusalem as a "Spanish Jew" who was also a defender of Spain. To reinforce his request, he argued that Spain had helped the Jews in Europe during the Second World War. At the same time, Nesry declared himself an advocate of the "cause," which must be understood in this context as the Zionist cause or the cause of Israel: "More realistically, no one can underestimate the moral support that the international influence of Spain would bring to our cause, particularly in Spanish America [...] In compensation, it is logical to foresee that, within the limits of its efficiency, the international influence of the Jewish world could be exercised along the lines and in the direction of the interests of Spain." 18

\footnotetext{
16 "Coded telegram No. 54 from the Ministry of Foreign Affairs of Spain to the Consul General of Spain in Tangier," Madrid, May 1948 (CGE Tangier, Israelite Policy, 1948-1955).

17 "Coded telegram No. 82 from the General Consul of Spain in Tangier, Cristobal del Castillo, to the Ministry of Foreign Affairs of Spain," Tangier, May 1948; "Coded telegram No. 85 from the General Consul of Spain in Tangier, Cristobal del Castillo, to the Ministry of Foreign Affairs of Spain," Tangier, May 1948; "Coded Telegram from the General Consul of Spain in Tangier, Cristobal del Castillo, to the Ministry of Foreign Affairs of Spain," Tangier, 19 May 1948; "Dispatch No. 541 from the General Consul of Spain in Tangier, Cristobal del Castillo, to the Ministry of Foreign Affairs of Spain," Tangier, 28 May 1948; several undated telegrams from Carlos Nesry to the Israeli Ministry of Foreign Affairs from Tangier (CGE Tangier, Israelite Policy, 1948-1955).

18 "Letter from Carlos J. Nesry to the General Consul of Spain in Tangier," Tangier, 3 June 1948 (CGE Tangier, Israelite Policy, 1948-1955).
} 
These mixed loyalties were not uncommon among the Sephardic elites of northern Morocco and Spain, as seen in the case of Bauer during an earlier period. ${ }^{19}$ Like Bauer, Nesry also celebrated philo-Sephardism, referring to historical and cultural ties, and noted that the establishment of diplomatic relations with Israel would reinforce the work of recovering Spanish-Jewish culture in Spain. He praised the Arias Montano and Maimonides Institutes and Professors Millàs Vallicrosa and Cantera Burgos for their work in recovering the Hispano-Jewish past. ${ }^{20}$ Similarly, Nesry argued for-if not the establishment of diplomatic relations between Israel and Spain - the establishment of, at least, "friendly" relations. This was a hasty move on the part of Nesry, since the Spanish government feared an adverse reaction from the Arabs if Spain recognized Israel. The sultan in Rabat had already warned that it would be difficult to maintain order in Morocco if France recognized the Jewish state. In response, Spain argued that the Spanish government was particularly concerned about the safety of the Jews in Morocco: "If Mr. Nesry is able to speak with Your Excellency regarding the recognition of the State of Israel, Your Excellency can $[\ldots]$ personally state that our greatest concern today is the defense of the Jews of Morocco, especially after the declaration of the sultan of Rabat." ${ }^{21}$

In the mid-1950s, Spain began to open up more to the outside world. Having been admitted to the United Nations in December 1955, the country no longer required Israel's support or was interested in establishing diplomatic relations with the Jewish state. However, it engaged in occasional exchanges with that country on some issues, such as cultural affairs. Spain had long-term religious and cultural ties with Palestine, where it hosted various missions and religious institutions, though mostly in the old city, which was controlled by Jordan at that time. The Sephardic connection was also undoubtedly an important meeting point. From at least 1950, the consulate of Spain in Jerusalem sent lists of professors and academic institutions in Israel to the Ministry of Foreign Affairs, along with their postal addresses, requesting that the journal Sefarad be mailed to them. Likewise, the Franco government financed a Spanish lecturer at the Hebrew University of Jerusalem beginning sometime around 1956, the same post that had been occupied by Josep Maria Millàs Vallicrosa in 1937 and $1938 .^{22}$

\footnotetext{
19 Although Bauer had an Ashkenazi background, he embraced the philo-Sephardic cause and was one of its main sponsors.

20 "Letter from Carlos J. Nesry to the General Consul of Spain in Tangier," Tangier, 3 June 1948 (CGE Tangier, Israelite Policy, 1948-1955).

21 "Coded telegram No. 65 from the Ministry of Foreign Affairs of Spain to the General Consul of Spain in Tangier," Madrid, 5 June 1948 (CGE Tangier, Israelite Policy, 1948-1955); see also Bin-Nun, "The Disputes Regarding the Jewish Emigration from Morocco 1956-1961” (Bin-Nun 2013).

22 "Letter from $\mathbf{M}^{\mathrm{a}}$ Pilar Bermejo from the Teresina Institution to Don José Antonio Balenchana," Jerusalem, 28 August 1959 (AGA, 66/04588); "Lists of names and institutions to send 'Sefarad' provided by Professor Beinart, 1951 and 1953" (AGA, 66/04588); "Lecturer of Spanish at the Hebrew University of Jerusalem, Memoir, Academic Year 1956-1957,” Jerusalem, July 1957 (AGA, 66/04588).
} 


\section{Aliyah Bet, Emigration to Israel through North Morocco}

The first migration wave of Jews from the Spanish zone of Morocco, Tangier, and the Spanish cities of Ceuta and Melilla occurred as early as $1948 .^{23}$ On 9 April 1949, the Ministry of Foreign Affairs of Spain's General Directorate of Africa and the Near East informed the Consul General of Spain in Tangier about the "Emigration of Moroccan Jews to Palestine." 24 This report included a copy of an earlier dispatch on the subject sent by the Spanish chargé d'affaires in Beirut to the Ministry of Foreign Affairs. There, the representative in Beirut reported on rumors about the intensification of the secret flight of Jews from Morocco to Palestine. ${ }^{25}$ That same year, the Military Tribunal of Malaga began prosecution of several young men from Melilla and Villa Nador in the Spanish Protectorate who had not attended the call to compulsory military service for their age group in 1948 but had instead left for Palestine. $^{26}$

Before Moroccan independence, emigration to Israel from the northern part of the country was generally via Tangier to Marseilles or Gibraltar and from there to Israel on board Israeli transatlantic vessels or planes, although some groups may also have embarked on the transatlantic Israeli ships that were starting to make stopovers in Ceuta on their New York-Israel route between 1954 and 1955. Fears regarding the incipient Moroccan independence were probably behind the search for new ports for the émigrés (Laskier 1989, 1994; Bin-Nun 2013; Benchetrit 2017). In 1954, the ZIM Company's transatlantic vessel "Jerusalem" began to stop in that city to refuel on its way from New York to Haifa. The company Atlas of Ceuta was the local consignee of ZIM. In 1955, the representative of ZIM wrote a memorandum explaining that the first shipment of passengers departing from Ceuta, who had arrived in the city from Tangier and French Morocco, was going to take place. The ZIM representative asked the Spanish authorities for permission to hold a reception on the "Jerusalem" to celebrate the first passenger boarding from Ceuta. At the ceremony, they wished to invite some one hundred Jewish people from Tetouan, Tangier, and Ceuta who might be interested in traveling with the shipping company in the future. Documents written shortly thereafter indicate that several shipments from Ceuta did not, in fact, have ordinary passengers on board, but entire families emigrating to Israel.

The first shipment, which left on 1 May,1955-for which only a continuation sheet containing 46 names remains-probably consisted of a group of at least a hundred passengers. On this first sheet, after "Ceuta" the word "Gibraltar" appears crossed out. On 1 June,1955, a new list documented the departure of 241 people

\footnotetext{
23 "Dispatch No. 283 from the Consul General of Spain to the Commanding Judge Instructor of Recruit Box No. 1 of Malaga," Jerusalem, 4 December 1950 (AGA, 66/04706).

24 "Dispatch No. 139 from the Ministry of Foreign Affairs of Spain's General Directorate of Africa and the Near East to the Consul General of Spain in Tangier," Madrid, 9 April 1949 (CGE Tangier, Israelite Policy, 1948-1955).

25 "Copy of Dispatch No. 47 of the chargé d'affaires of Spain in Beirut to the Ministry of Foreign Affairs,” Beirut, 22 January 1949 (CGE Tangier, Israelite Policy, 1948-1955).

26 José Bensuan Cohen; Isaac Bitan Sultan; Mojluf Levy Farache; Salomón Levy Levy; David Sadia Bitan Arrabi; Sadia Benhamu Levy; Mesod Elmalek Benhamu (AGA 66/04706).
} 
from Ceuta. Again, the word "Gibraltar" is crossed out. The coincidence of dates and this corrected "error" suggest that these people had, indeed, embarked in Ceuta to go to Israel. One month later, another departure from Tangier to Ceuta of 173 people took place, but the word Gibraltar no longer appears on the document. ${ }^{27}$

Most of the people on these lists were families with young children who emigrated to the Jewish state, largely nuclear families with from three to ten people, that is, a father, mother, and their children. Only exceptionally does an elderly relative appear in the groups. The composition of some of these groups is quite illustrative. One example is the Dadon family. The father, David Dadon, born in 1895, was traveling with his wife and five children between the ages of ten and twenty. Although David Dadon was born at the end of the nineteenth century, there are very few cases of people on these lists born before the twentieth century. Alia Kadosh is the oldest traveler on the lists. Born in 1880, he was 75 years old at the time of emigration, an extraordinary fact for two reasons. In the first place, for the most part the elderly did not consider emigration an option, rather wanting to spend the rest of their days in the city where they had been born, such as Tetouan; and secondly, in its struggle for survival, the State of Israel wanted young, healthy people with no criminal record. ${ }^{28}$

The same Ceuta file for 1 June 1955 includes a list of Jewish emigrants sailing from Tangier to Gibraltar. The date coincides with the most significant departure documented to date from Ceuta of almost 300 people, with the Tangier group alone including 146 people. In this occasion they were being taken to Gibraltar, whence they would undoubtedly embark towards Israel. ${ }^{29}$ Nothing on the lists indicates the origin of these individuals. However, their last names and, above all, their first names, suggest that the majority were Sephardic Jews. The last names of Spanish origin, for example, include Toledano and other common Jewish last names among Iberian Jews in Morocco such as Salama, Garzón, and Nahón. The lists include Spanish forms of male and female names such as Alberto, the preferred Sephardic Spanish version of Abraham, and Mercedes. Most notable, however, are the female naming traditions whose origins date back to the medieval Iberian kingdoms, such as Fortuna, Sol, Alegría, Estrella, Vida, and Flora. The combination of first and last names on the family lists indicates that these were most certainly Sephardic families. $^{30}$

\footnotetext{
27 "Memorandum by R. M. Mayer of the ZIM Company," Tangier, 21 March 1955; "Dispatch No. 51 from the Head of the General Consulate of Spain in Tangier to the High Commissioner of Spain in Morocco," 21 March 1955 (CGE Tangier, Israelite Policy, 1948-1955). "Departure from Tangier of 1 June 1955, Gibraltar" (CZA, L28/157).

28 "Memorandum by R. M. Mayer of the ZIM Company," Tangier, 21 March 1955; "Dispatch No. 51 of the Head of the General Consulate of Spain in Tangier to the High Commissioner of Spain in Morocco," 21 March 1955 (CGE Tangier, Israelite Policy, 1948-1955); "Discourse of the Head of State, David Ben Gurion to the Knesset on 5 January 1951" (AGA, 66/04530, Press 1950-1977). See also Benchetrit, El mazal de los pobres (2017).

29 "Departure from Tangier of 1 June 1955, Gibraltar" (CZA, L28/157).

30 "Continuation sheet Departure of 1 May 1955 from Ceuta;" "Departure of 1 June 1955 from Ceuta;" "Continuation sheet Departure of 1 June 1955 from Ceuta;" "Departure from Tangier 8 July 1955, Ceuta" (CZA, L28/157).
} 
With the independence of Morocco and the prohibition forbidding Jews from going to Israel, the northern part of the country began to play a more important role thanks to its land border with the Spanish enclaves of Ceuta and Melilla. There were three basic exit routes from the northern zone in that period: from the eastern part of the country to Oujda and Algeria; from the center and the Rif to Melilla and Malaga-Gibraltar; and from the western area via Tangier or Tetouan to Ceuta and Algeciras-Gibraltar. Nevertheless, because Casablanca became the main transit center for southern Jews, groups heading for Ceuta and Melilla also left from there. Fez served as another important transit point. To a lesser extent, the small Spanish islands of Chafarinas and the rocky outcroppings of Alhucemas and Velez de la Gomera on the Mediterranean coast of Morocco were also used as a way out.

Aliyah Bet-underground emigration-required a decentralized method of organization, and local activists who were recruited formed independent cells in Tetouan, Ceuta, and Melilla, as well as Tangier and Gibraltar. These local cells played a fundamental role in this period, organizing groups and the departures of the Moroccan Jews. The Tetouan and Ceuta groups, for example, were made up of a local team of at least six or seven people. The group in the eastern Rif, with its center in Melilla, was probably smaller, constituting only three or four individuals. The local agents in each zone organized the departures for small groups with little luggage on pre-established routes. These departures took place two or three times a month, always in coordination with the leaders of Misgeret-an underground organization created by the Mossad in 1955 to continue their operations after Moroccan independence-in the northern zone. To avoid being discovered, the groups of emigrants were not informed of the planned day for their evacuation, but only notified of the time and place that a vehicle was to pick them up to drive them to the border a few hours beforehand. Often these transfers were made at night. To pass through the Moroccan exit checkpoints, Israeli agents or local activists bribed the border police, as the migrants lacked passports or had only false documents provided by Misgeret. However, due to the decentralization of operations, the local activists in each zone acted in very different ways, taking advantage of the opportunities available at each moment, although always in coordination with the representatives of the Mossad (Knafo 2008, 195-290).

Despite its efforts, the Moroccan government failed to destroy these underground networks. However, between 1956 and 1961, several members of the local Misgeret cells were arrested, tortured, or expelled from the country if they were foreigners. The same happened with underground emigrants if they were intercepted in flight, as occurred several times in Tetouan, and with the taxi drivers and smugglers who were recruited for these transports. Perhaps to better detect these networks, the Makhzen appointed a Jew originally from the North, Abraham Israel, as Senior Security Commissioner in 1958. Israel had jurisdiction over the entire Moroccan territory in matters of emigration, only subordinate to 
national security. The Spanish authorities were pleased with this appointment, as they believed that "in this person, Spain has a safe friend" because of his family ties with the Spanish state. Israel was the nephew "of a distinguished Israeli family of recognized sympathy for Spain, since his uncles Messod and Isaac Bendrao, from the first days of the National Uprising, rendered services in favor of the Crusade." It was also noted that because of his position, he would have to "act tactfully.",31

The role of Ceuta and Melilla as alternative routes for the evacuation of Moroccan Jews intensified after 1957 when difficulties and controls affecting the departure of illegal immigrants from Tangier increased. The international city had continued to enjoy a somewhat exceptional situation after Moroccan independence while preparing to integrate with the rest of the country. Beginning in the summer of 1957 , when the Moroccan government intensified controls over Jews from Morocco leaving through that city, Misgeret agents began to divert departures to Ceuta through Tetouan. That same year, the Moroccan police intercepted one of the first convoys transferred from Tangier on that route, and more than 200 emigrants were arrested and interned in Tetouan (Knafo 2008, 223, 286-289, 313). In view of this situation, the evacuation of the Moroccan Jews required new strategies and routes. These involved more isolated, grueling, and risky journeys through the mountains or by sea, and in much smaller groups that could more easily avoid police controls. It also meant the need to mobilize social networks beyond the local Jewish communities. Here, Ceuta and the group led by Carlos Medina Santiago, and Melilla and the group led by José Suisa Chocrón, would play a fundamental role.

Carlos, or Shalom, Medina was a Ceuta Jew born around 1920. He was the son of Isaac Medina Wahnon, whose father, Marcos Medina, a convert to Judaism, had arrived in Ceuta from Larache at the end of the nineteenth century. He was married to Simi Wahnon. Carlos Medina's mother also converted to Judaism in order to marry Isaac Medina and went from being Concepcion Santiago to Sarah Santiago; hence Carlos's two last names: Medina and Santiago. Like many Jews in Republican Spain, Carlos's father and uncle were members of the Republican parties, particularly Izquierda Republicana, and the masonry, and were repressed by the Franco regime. Isaac Medina was a friend of the mayor of Ceuta during the Republic, the socialist Antonio López Sánchez-Prados, who would be executed after the military uprising. Isaac Medina, in turn, was imprisoned for eight years and lost everything. ${ }^{32}$ Carlos Medina also married a woman from outside the Jewish community. He fell in love with Antonia Rodríguez, who converted to Judaism and was renamed Rachel. ${ }^{33}$ This genealogical information is not merely anecdotal, but shows the fluidity of social relationships despite interreligious borders in the protectorate. Above all, it illustrates the extent of the networks that the members of Misgeret were able to mobilize beyond the Jewish communities.

\footnotetext{
31 Abraham Israel Personal File, 1958 (Ceuta Military Archive, AIMC, General Command of the North Africa Army, C.G. ENA, Collection F., 01-01, 257/156).

32 Isaac Medina Personal File, 1936 (AIMC, TRITE 2, 68/5).

33 Interview with M. I., Ceuta, May 2017.
} 
Carlos Medina seems to have inherited his father's political and social commitment. As a young man, he was a member of Jewish Moroccan youth movements. Later, Medina worked for the Jewish Agency in Morocco that was coordinating the departure of the groups leaving from the north between 1954 and 1964. During Aliyah Bet, Misgeret ordered Medina to take care of the selection of available boats to allow migrants to cross over the Moroccan Spanish border with Ceuta by sea, as land crossings through Moroccan controls became more complicated after 1959. He was also in charge of identifying reliable taxi drivers who could handle the transport of the emigrants in Morocco to the collection point to transfer them to Ceuta. Finally, he was responsible for contacting Moroccans who lived near the Moroccan border with Ceuta who might be willing to hide small groups of emigrants in their homes before they crossed the border at night. Misgeret agents in Ceuta assisted Medina with the passports and money needed for the operations, removing the mirrors from a closet to create a double bottom to hide the items in Medina's house. Most of these documents - mostly false passports - were later delivered to the organization's office in Gibraltar. The coordination meeting of Operation Fish-the code name used for the operation to smuggle emigrants from Morocco to Ceuta-was attended by the principal northern leaders of Misgeret in Ceuta on 18 December 1959. Hasdai Doron, the leader of Misgeret in Tangier, was present as was, of course, Medina, who had proposed this operation and established its guidelines (Laskier 1994, 222; Knafo 2008, 247, 277). ${ }^{34}$

From Oujda, Fez or Larache, but also Casablanca, groups were assembled to guide emigrants to Melilla. The local person in charge of the operations in the eastern Rif was José Suisa Chocrón. Like Carlos Medina, José Suisa was a Sephardic Jew and Spanish national. ${ }^{35}$ The Spanish Military Archives of Ceuta opened a personal file on Suisa that includes the comment that, "It seems that the Israelite in charge of Melilla to attend to his followers who flee from Morocco and go to Israel, via Gibraltar, is the so-called José Suisa Chocrón, a Spanish national."36 The military authorities also opened a file on Abraham Behar, attaché at the Embassy of Israel in Paris. Although there is no further information from the army records, he conveniently arrived in Melilla at the very time when underground departures from northern Morocco through the Spanish city had intensified: "The Israelite Abraham Behar, attaché to the head of the Embassy of Israel in Paris, has been in Melilla since the $7^{\text {th }}$, and according to some reports, he is dealing with matters related to the Israelite colony in Melilla." 37

Initially, the Rif route was organized with the participation of Spanish taxi drivers contacted by Suisa, who drove the groups leaving from Fez or Larache through the Rif to the nearby mountains of Melilla. Then, as in Ceuta, the migrants illegally crossed the Moroccan-Spanish border on foot with the help of local guides.

\footnotetext{
34 Interview with M. I., Ceuta, May 2017.

35 Suisa was probably under the command of Medina, who seems to have been the main local inhabitant responsible for the North (Interview with M. I., Ceuta, May 2017).

36 José Suisa Chocrón Personal File, 1961 (AIMC, C.G. ENA, F. 01-01, 384/15).

37 Abraham Behar Personal File, 1960 (AIMC, C.G. ENA, F. 01-01, 286/23).
} 
However, in the summer of 1959 there was a social uprising in the Rif, and the Moroccans canceled the entry permits to Spanish taxis. This prevented the taxi drivers from Melilla from leaving the city for the long periods required to drive the illegal emigrants along the lengthy Rif route to the Spanish city. Collaborators and drivers were also found among Moroccan Muslims, one example being Anita, a Riffian hajj who drove a Mercedes van and transported groups of Jews from cities as far away as Casablanca to Melilla. Coach service, from both Jewish and non-Jewish owners in Morocco, was also contracted (José Antonio Lisbona 1993, 194; Knafo 2008, 239-245).

Records from the Military Archive of Ceuta suggest that Misgeret agents were also operating in Alhucemas, one example being the personal file of Yahya Chekrum, of whom little is known other than that he was expelled from Alhucemas by the Moroccan authorities on 18 June $1959 .{ }^{38}$ There were also local collaborators, such as Jacob Levy Serfati. According to Spanish military records, he was an "Israelite resident of Villa Sanjurjo [Alhucemas] of anti-Moroccan tendency, influential in the Jewish community, manager of the Shell Station related to Israeli immigration." He was also an agent for the Transmediterránea company in the zone, and the note from the Spanish archive indicates that he organized the transport of emigrants under cover of his post there. ${ }^{39}$ Quite probably, Levy Serfati was a close collaborator of Suisa Chocrón in Melilla with regard to the evacuation of Moroccan Jews.

In addition, Spanish fishermen were hired to ferry the migrants in their boats from the Moroccan beaches to Ceuta and Melilla. Carlos Medina's brother-in-law through his wife Rachel lent his fishing boat for the illegal crossing from Morocco to Ceuta. A small vessel was also purchased in that city by Misgeret. Medina himself took out a boatmaster's license in December 1955 to sail the boat himself. The trips initially took off from the nearest Moroccan towns, embarking, for example, on the beaches of Castillejos (Fnideq). Later, as Moroccan control tightened, they had to depart from other locations such as the beach of Rincon (M'Diq), southeast of Ceuta, or even places as far away as Larache on the Atlantic coast, from which the trip lasted about twelve hours. The size of the groups depended on the chosen entry routes into Ceuta and Melilla and the means of transport, as well as the intensification of controls by the Moroccan authorities. Group sizes ranged from as small as three emigrants to around fifty, although the most common number was around a dozen emigrants per trip. No doubt, the complicity of Medina's and Suisa's

\footnotetext{
38 Yahya Chekrum Personal File, 1959 (AIMC, C.G. ENA, F. 01-01, 358/?).

39 Jacob Levy Serfati Personal File, 1961 (AIMC, C.G. ENA, F. 01-01, 322/64). The London Jew Marcus Samuel had founded the Shell oil company with the collaboration of the Rothschild House, which would later merge with Royal Dutch Petroleum forming Royal Dutch Shell. The Salama family of Melilla, a wealthy Jewish family from northern Morocco of Tetouan origin, represented Royal Dutch Shell in Spain and Morocco. This family also represented the Transatlantic Company, the Paquet Shipping Company, Crèdit Lyonnaise, and Lloyd's bank in Melilla, and had a branch office in Alhucemas and another in Ceuta (Vida Marroqui No. 439, January 1935, 6; (Llanos Alcaraz 1994, 344-49; Saro Gandarillas 1997a, b). I could not find any documentation to confirm whether the Salama family supported or facilitated the emigration of Moroccan Jews through Melilla, Alhucemas, or Ceuta in any way, but some relationship with the emigrations via the shipping companies for which they were consignees and representatives in the Spanish and Moroccan cities in North Africa is evident.
} 
non-Jewish contacts was important. For example, Salvador García-a sergeant with the Ceuta secret police-ordered two informants who worked for him to guide a group of emigrants to the embarkation point as part of Operation Fish. The Ceuta and Melilla cells, whose members knew the territory well, took advantage of events that attracted large crowds of people, such as the dates of the Jewish pilgrimages to the tombs of some tzaddikim from northern Morocco and several Christian celebrations, to camouflage the groups of underground emigrants (Lisbona 1993, 194; Knafo 2008, 239-247, 274-277). ${ }^{40}$

\section{Emigrants in Ceuta and Melilla and the Departure to Gibraltar and Israel}

Entering Spanish territory was not a problem, since Misgeret provided emigrants with short-term group safe passages to enter and leave Spain. They obtained them at the Spanish consulate in Tangier and the Spanish embassy in Casablanca, meaning that the consular authorities were granted the approval to give them out by Madrid. Once in Ceuta or Melilla, Carlos Medina and José Suisa organized accommodation in hotels for the emigrants for one night. Some witnesses also report having seen groups of Jews waiting for a few hours in an enclosed area near the port and even in the patio of the Ceuta Civil Guard headquarters. ${ }^{41}$

Like the embassy in Casablanca and the consulate in Tangier, the Spanish police and military authorities in the north African Spanish cities required permission from Madrid to allow the illegal Moroccan emigrants to enter Spain from Morocco on their way to Gibraltar. The Misgeret agents informed the local authorities of the landing points, if they were entering by sea, or the mountain routes when the entry was made by land to avoid the Moroccan border. The police and army also documented these entrances and exits to ensure that all those who arrived in Ceuta or Melilla left immediately afterwards. For example, on 9 September 1958, 159 people from Tangier embarked in Ceuta, and both the entrances and exits were registered by the military. The last and, above all, first names suggest, again, that a large part of these emigrants were Sephardic Jews: Guillermo, Alberto, León, Sol, Estrella, Mercedes, Elías, José, and Salomón, among others. There were also nuclear families with young children, and the groups consisted of between three and ten people, occasionally rising to twelve. The appearance of French Christian names on the lists interspersed between the names in Spanish/Haketia and the Hebrew names shows the influence of French culture through the work of the AIU schools. The Spanish civil registries for the north African cities also recorded any undocumented babies in the groups, so that the local Misgeret agents could include them in their parents' travel documents, allowing them to leave Ceuta and Melilla legally. ${ }^{42}$

\footnotetext{
${ }^{40}$ Interview with M. I., Ceuta, May 2017.

41 Interview with H. J., Ceuta, May 2017; Interview with M. E., Barcelona, January 2017; Interview with M. I., Ceuta, May 2017.

42 "Departure from Tangier via Ceuta, 9 September 1958” (CZA, L28/157).
} 
The Spanish authorities in Ceuta and Melilla also watched discreetly to ensure that the emigrants entered and exited without any major incidents from the moment the Moroccan Jews set foot in those cities. Hasdai Doron reported several cases that demonstrated the good rapport between Carlos Medina and the Spanish police regarding the smooth evacuation of Moroccan Jews once in Spanish territory. On one occasion, for example, Medina was confronted with the demands of a Roma family camped out near one of the landing points, whose leader demanded a bribe for each disembarked emigrant. Otherwise he threatened to inform the Moroccan authorities, sabotage the boat holding the underground emigrants, and even stab Medina. The local Misgeret agent reported this affair directly to the Ceuta police chief, who ordered the arrest of all the men in the Roma family and issued an order to expel the entire group from Ceuta. They were transported under police custody to Algeciras and warned that if they touched Medina or carried out any of their threats, they would be imprisoned for life. ${ }^{43}$

The journeys between Ceuta and Algeciras or Melilla and Malaga were made in commercial vessels. From Algeciras or Malaga, the migrants were taken to Gibraltar, passing through the small town of La Linea de la Concepción, where they spent another night if needed. During this period, Gibraltar played the role of liaison between the activists in Morocco, Ceuta, and Melilla, and the Jewish Agency that had a representative in the British Overseas Territory. Through the Israeli consulate in Gibraltar, the local chargé at the Jewish Agency arranged for passage for the emigrants on Israeli transatlantic ships or flights bound for Israel. The ships that carried the immigrants from Gibraltar to the Jewish state were the "Zion" and the "Israel." Although the Gibraltar authorities rarely recorded the passage of these transatlantic ships, a cargo of "emigrants" on board one of these vessels occasionally appears in their records. Neither is it easy to track the emigrants in the local press, beyond the odd small note. Both in Spain and Gibraltar, all the operations were conducted discreetly, and it is more than likely that the Spanish and British authorities prevented the press from reporting the story to avoid problems with Morocco and other Arab states. Nevertheless, the size of the groups and their concentration in Catalan Bay behind Gibraltar did not go unnoticed by the local population. ${ }^{44}$

Not all the actions were successful and not all the groups reached Gibraltar. In the best of cases, the emigrants were intercepted by the Moroccan police and imprisoned, as happened in Tetouan with the Operation Sardine group on their way to Melilla (Knafo 2008, 244, 278). Carlos Medina himself was sought by the Moroccan authorities and his wife was almost arrested when she went to the border with her baby in her arms to ask the Moroccan police if they had seen her husband. A Moroccan police officer warned Medina's wife of the situation and told her to return

\footnotetext{
43 Interview with M. I., Ceuta May 2017; see also Knafo, Le Mossad et les secrets du réseau juif au $\operatorname{Maroc}(2008,274-275)$.

44 "La flota mercante de Israel," El Calpense, Gibraltar, 22 February 1956; "Emigrantes Judíos para Israel," El Calpense, Gibraltar 23 February 1956. Port Dept. Look-out log book 1961 (Gibraltar National Archives). See also Knafo, Le Mossad et les secrets du réseau juif au Maroc (2008, 126-132, 214, 238239, 257-258). Interview with M. J., Gibraltar, May 2017.
} 
immediately to Ceuta or face detention herself. Medina and his group were then forced to return to Ceuta through the mountains. In the worst of cases, the emigrants could suffer accidents and even lose their lives. On one of the trips, at night and in silence to avoid detection by Moroccan guards, a mother accidentally suffocated her baby trying to silence the baby's cry; the remains lie in the Ceuta cemetery. ${ }^{45}$ Hasdai Doron was also worried about the capacity and commitment of some of the local agents. He was in Melilla at the end of 1959, and in his report to the Paris headquarters dated 7 January 1960, he commented on the need to immediately replace some local Misgeret members in Melilla. Otherwise, he feared, "this place will rot in a deep and dangerous lethargy." The local members referred to were Elías Chocrón and Sam Benzaquén; Doron did not mention José Suisa. This opinion coincides with that expressed later by Carlos Medina regarding the shipwreck of the "Pisces" (known in Hebrew as Egoz), which occurred in early 1961. For Medina, the accident was caused by the mismanagement and negligence of the Melilla cell (Knafo 2008, $244,278) .^{46}$

The sinking of the "Pisces" with more than forty emigrants on board off the coast of Alhucemas was the most dramatic episode of Aliyah Bet from Morocco. Carlos Medina oversaw the recruitment of the group of emigrants, some of whom, like the Maman family, came from far-away Casablanca. Together with Suisa Chocrón, Levy Serfati managed the transport of these emigrants on board the "Pisces," a ship based in Gibraltar and owned by a British citizen. This freighter was able to transport several dozen emigrants on long journeys between a beach in northern Morocco and Gibraltar, about $300 \mathrm{~km}$, distances that regular fishing boats could not cover with that weight. In addition to transporting a larger group, this ship could take more direct routes that avoided a number of stopovers. On all the trips made by the "Pisces," a Misgeret agent accompanied the emigrants and was in direct contact by radio with Gibraltar and Paris. According to Michael Knafo, the idea came from the Paris headquarters of the Mossad, which sought to end its dependence on the smugglers from Ceuta, Melilla, Gibraltar, and Algeciras. However, this initiative initially encountered strong opposition, as some, like Medina, considered such crossings very dangerous, arguing that it was safer to sail along the coast to Ceuta or Melilla, where the emigrants would legally embark on a regular transport. However, the perception of increasing uncertainty and insecurity for the Jews in Morocco justified the risky decision, which later proved to have dramatic consequences (Knafo 2008, $36-38,450) .{ }^{47}$

When the "Pisces" sank, it also had a powerful impact on Levy Serfati, who was "very affected by the shipwreck and death of the Jews who were traveling there," 48 as well as on other people who had some direct or indirect relationship with this group of emigrants. The tragedy of the "Pisces" shipwreck revealed the activities of

\footnotetext{
45 Interview with M. I., Ceuta, May 2017.

46 Interview with M. I., Ceuta, May 2017.

47 Interview with M. I., Ceuta, May 2017.

48 Jacob Levy Serfati Personal File, 1961 (AIMC, C.G. ENA, F. 01-01, 322/64).
} 
the Zionist agents in Morocco and attracted international attention to the plight of the country's Jews and their perilous flight. According to oral history interviews and memoirs, most of the Jews who migrated this way did not have the economic and social resources to legally leave Morocco for a third country, like France or Spain, before undertaking Aliyah. ${ }^{49}$

After the death of Mohamed V and the ascension of Hassan II a few months later, Moroccan policy regarding the emigration of its Jews to Israel became more flexible, and some 80,000 more people were able to leave for that country between 1961 and 1964. During that period, Mossad agents maintained close ties with Hassan II, who was trying to discreetly distance himself from Gamal Abdel Nasser in Egypt and the Arab League. In these negotiations, the orderly departure of a good part of the remaining Moroccan Jews was agreed upon in exchange for significant economic compensation, and Operation Yakhin began (Bensimon 1991; Knafo 2008; Bin-Nun 2014).

Once in Israel, not all the Jews adapted to the country. In 1956, the consul of the Spanish Republic in exile, Carlos Noguera Samuel, affirmed that he was often approached by Jews from Spanish Morocco asking him to provide them with passports to go to Latin America. These immigrants had not adapted to the hard life in the border kibbutzim. The consul in exile, however, rejected their requests:

Don Carlos told us about the immigrants from Spanish Morocco who arrived in Israel and found their way to his apartment [...] Everyone wanted one thing: [...] a passport to [...] go to Latin America. They are not happy with life in the border colonies to which they were sent. However, Don Carlos [who] is a good Jew and a good Zionist refuses: "What? You want to leave? You must not leave; [I] also spent five years in a kibbutz in Caesarea, look at my calloused hands." 50

After the end of the Aliyah operations in Morocco in the mid-1960s, Israel offered the local Misgeret activists jobs and housing in the Jewish state. José Suisa accepted, but Carlos Medina chose to stay in Ceuta, despite having a sister and brother who had emigrated to Israel in those difficult years. Even so, his political and social commitment would continue. Because of his sympathies with the Labor Party of Israel, he was watched and classified as a "Red" by the Franco government. He later entered the Spanish Socialist Workers Party. ${ }^{51}$

\footnotetext{
49 Interview with H. J., Ceuta, May 2017; Interview with M. I., Ceuta, May 2017. In his ethnographic novel El mazal de los pobres [The Luck of the Poor] on Tetouan, Elie Benchetrit shows the different emigration routes taken by a group of Zionist youth from Tetouan, the wealthiest of them leaving the country as tourists and going to Marseille, the site of a transit camp where they registered for emigration to Israel, while the less wealthy had to leave Morocco illegally, taking more dangerous routes. This suggests that many lacked not only financial capital, but also the other capitals discussed by Bourdieu (social, cultural, and symbolic) to be able to consider other migration options; this is true of the emigrants interviewed by Aviad Moreno and Angy Cohen in Israel, Venezuela, and Argentina (Bourdieu 1979; Cohen and Moreno 2017; Cohen 2017; Moreno 2020)

50 “'J'ai fêté à Tel-Aviv l'anniversaire de la République Espagnole' par Shaul Ben Haim (traduction littérale)," Maariv 21 April 1956 (AGA, 66/04602).

51 Interview with M. I., Ceuta, May 2017.
} 


\section{Conclusion}

The political experience of the Jews of North Morocco during the nineteenth and twentieth centuries is often underestimated, because the experience of the Jews from the French Protectorate, where the bulk of the Jewish population of that country resided, is simply used as a model. However, the historical-political experience of northern Moroccan Jews during those two centuries is specific enough to deserve a separate chapter. This distinctiveness is not only ignored by the main academic currents today, but was also overlooked by the Zionist agents of the time. The initial resistance of the Jews of North Morocco to Zionism was due to the fact that they viewed it not only as an irreligious ideology, but also as a movement that disregarded their Sephardic particularity. On the contrary, the Spanish colonialists quickly recognized how the Sephardic Jews of North Morocco could serve Spain's colonial ambitions. The cultural proximity of the Sephardim was used as an instrument for Spanish foreign policy beginning in the late nineteenth century. Spanish-Sephardic relations intensified and the Moroccan Sephardim started to settle in the Spanish former military city-garrisons of Ceuta and Melilla. This does not mean that anti-Jewish and anti-Semitic prejudices were not present or that Sephardic cultural and religious identity became diluted. However, both the colonial and Sephardic upper classes saw the benefits of the association. Mutual interest among Spanish and Sephardic political and intellectual elites and a curious mixture of Hispanism and Zionism characterized Sephardic Zionists in Spain and Morocco.

After the creation of the State of Israel, the fluidity of relations between the Spanish authorities in Morocco and the economic and intellectual Sephardic elites survived, despite the nonexistence of diplomatic relations between David Ben-Gurion's Israel and Francisco Franco's Spain. The Spanish authorities once again turned to their contacts among the Sephardim of Morocco, on this occasion to obtain a commitment from Israel to respect the Holy Places in Palestine in the event of a conflict between Israel and its Arab neighbors.

These informal relations acquired new significance with the emigration of Jews from Morocco to Israel, especially after Moroccan independence in 1956. When Morocco closed the usual exit routes-Casablanca in the south and, later, Tangier in the north - the mobilization of local Zionist activists was fundamental to be able to continue taking people out of the country. These local activists were Sephardic youth from the former Spanish Protectorate and cities under Spanish sovereignty, some of whom were also Spanish citizens. The local cells not only knew the territory well but could mobilize different social relations within and outside the Jewish community to smuggle Jewish emigrants out of Morocco. The discreet help, or at least laissez-faire attitude, of the Spanish authorities in Ceuta and Melilla undoubtedly facilitated transit through those cities. As during World War II, the ambivalent and utilitarian nature of philo-Sephardism allowed both non-Sephardic and Sephardic Jews-particularly the less wealthy ones-to pass through the country on the way to further destinations, but not to settle on Spanish soil (Rother 2005; Ojeda-Mata 2012). 


\section{References}

Abécassis, Frédéric, and Karime Dirèche. 2012. "Introduction.” In La Bienvenue et l'adieu: Migrants Juifs et Musulmans Au Maghreb (XVe-XXe Siècle) I, 17-36. Casablanca: La Croisée des Chemins.

Abitbol, Michel. 1982. Maghreb, Un Sionisme Religieux. Sillages 7: 55-68.

Álvarez Chillida, Gonzalo. 2002. El Antisemitismo En España: La Imagen Del Judío (1812-2002). Madrid: Marcial Pons.

Azoulay, Arieh. 2014. Jeunesse Dans La Tourmente. Les Mouvements de Jeunesse Juifs Au Maroc 19441964. Jerusalem: Elkana.

Baïda, Jamaâ. 2011. The Emigration of Moroccan Jews. In Jewish Culture and Society in North Africa, ed. EmilyBenichou Gottreich and Daniel J. Schroeter, 321-333. Bloomington: Indiana University Press.

Bauer, Ignacio. 1938. "Les Israélites Dans Le Rif.” In Comptes Rendus Du Congrès International de Géographie de Amsterdam de 1938, 349-350. Leiden: Brill.

Benchetrit, Elie. 2017. El Mazal de Los Pobres. Madrid: Hebraica Ediciones.

Bensimon, Agnès. 1991. Hassan II et Les Juifs: Histoire d'une Émigration Secrète. Paris: Seuil.

Bin-Nun, Yigal. 2013. The Disputes Regarding the Jewish Emigration from Morocco 1956-1961. In Jews and Muslims in the Islamic World, ed. Bernard Dov Cooperman and Zvi Zohar, 51-99. Bethesda: University Press of Maryland.

Bin-Nun, Yigal. 2014. The Reasons for the Departure of the Jews from Morocco, 1956-1967. In Postwar Jewish Displacement and Rebirth: 1945-1967, ed. Françoise S. Ouzan and Manfred Gerstenfeld, 196-211. Leiden: Brill.

Botbol Hachuel, Abraham. 1997. La Comunidad Judía de Tetuán y El Sionismo. Magen-Escudo 104: 5-7.

Bourdieu, Pierre. 1979. La Distinction: Critique Sociale Du Jugement. Paris: Éditions de Minuit.

Brodsky, Adriana Mariel. 2016. Sephardi, Jewish, Argentine: Creating Community and National Identity, 1880-1960. Bloomington: Indiana University Press.

Calderwood, Eric. 2018. Colonial Al-Andalus: Spain and the Making of Modern Moroccan Culture. Cambridge: Harvard University Press.

Calderwood, Eric. 2019. Moroccan Jews and the Spanish Colonial Imaginary, 1903-1951. Journal of North African Studies 24 (1): 86-110.

Campoy-Cubillo, Adolfo. 2012. Memories of the Maghreb: Transnational Identities in Spanish Cultural Production. New York: Palgrave Macmillan.

Cohen, Angy, and Aviad Moreno. 2017. Revisiting Morocco from Israel and Argentina: Contrasting Narratives About the 'Trip Back' Among Jewish Immigrants from Northern Morocco. Journal of Jewish Identities 10 (1): 173-197.

Cohen, David. 1980. Lyautey et Le Sionisme, 1915-1925. Outre-Mers. Revue d'histoire 67 (248-249): 269-300.

Cohen, Maria Angeles. 2017. Recordar, Resistir, Apostar: Conversaciones Con Judíos Hispano-Marroquíes En Israel y Argentina. Universidad Autónoma de Madrid/The Hebrew University of Jerusalem.

Díaz Más, Paloma. 1986. Los Sefardíes: Historia, Lengua y Cultura. Colección Aula Hispánica. Barcelona: Riopiedras Ediciones.

Fernández Díaz, María Elena. 2012. Hebreos y Musulmanes Durante La Guerra Civil En Melilla. Historia Contemporánea 24: 229-266.

Friedman, Michal. 2011. Reconquering 'Sepharad:' Hispanism And Proto-Fascism in Giménez Caballero's Sephardist Crusade. Journal of Spanish Cultural Studies 12 (1): 35-60.

Gómez Barceló, José Luís. 2012. Los Anuarios de Marruecos de La Editorial Ibero-Africano-Americana (1917-1930). In Protectorado Español En El Norte de Marruecos. Estudios y Percepciones Sobre La Cultura y El Movimiento Nacionalista, 1-25. Tetuán: Asociación Tetuán ASMIR.

Gómez Barceló, José Luís. 2014. Presencia y Vida de Los Judíos En La Ceuta de Los Siglos XV A1 XX. In Los Judíos En Ceuta, El Norte de África y El Estrecho de Gibraltar. XVI Jornadas de Historia de Ceuta, 185-276. Ceuta: Instituto de Estudios Ceutíes. 
González González, Irene. 2013. La Alianza Israelita Universal a Través Del Prisma Del Norte de Marruecos: Su Labor Educativa (1862-1912). In Judios Entre Europa y El Norte de África (Siglos XVXXI), ed. Eloy Martín Corrales and Maite Ojeda Mata, 73-92. Barcelona: Bellaterra.

Guershon, Isaac. 1996. The Foundation of Hispano Jewish Associations in Morocco, 181-189. In Sephardi and Middle Eastern Jewries: History and Culture in the Modern Era.

Israel Garzón, Jacobo. 2008. Los Judíos Hispano-Marroquíes (1492-1973). Madrid: Hebraica.

Knafo, Michel. 2008. Le Mossad et Les Secrets Du Réseau Juif Au Maroc 1955-1964. Paris: Biblieurope.

Laskier, Michael M. 1983. The Evolution of Zionist Activity in the Jewish Communities of Morocco, Tunisia and Algeria: 1897-1947. Studies in Zionism 4 (2): 205-236.

Laskier, Michael M. 1985. Zionism and the Jewish Communities of Morocco: 1956-1962. Studies in Zionism 6 (1): 119-138.

Laskier, Michael M. 1989. Jewish Emigration from Morocco to Israel: Government Policies and the Position of International Jewish Organizations, 1949-56. Middle Eastern Studies 25 (3): 323-362.

Laskier, Michael M. 1994. North African Jewry in the Twentieth Century. London: New York University Press.

Leibovici, Sarah. 1984. Chronique Des Juifs de Tétouan 1860-1896. Collection Judaïsme En Terre d'Islam 3. Paris: Editions Maisonneuve \& Larose.

Lisbona, José Antonio. 1993. Retorno a Sefarad: La Política de España Hacia Sus Judíos En El Siglo XX. Barcelona: Riopiedras.

Lisbona, José Antonio. 2000. Las Relaciones Diplomáticas España-Israel: 1948-1986. In Los Judíos En La España Contemporánea: Historia y Visiones, 1898-1998, ed. Uriel Macías Kapón, Yolanda Moreno Koch, and Ricardo Izquierdo Benito, 201-236. Cuenca: Ediciones de la Universidad de Castilla-La Mancha.

Lisbona, José Antonio. 2002. España-Israel: Historia de Unas Relaciones Secretas. Madrid: Temas de Hoy.

Llanos Alcaraz, Adolfo. 1994. La Campaña de Melilla de 1893-1894. Málaga: UNED Melilla.

López Álvarez, Ana María. 2004. Tetuán y Los Judíos. La Vida Cotidiana En El Noticiero de Tetuán (16 de Agosto de 1860-13 de Febrero de 1861). Akros 4: 57-70.

Marchán Gustems, Jesus. 2014. Afinidades Coloniales. La Propiedad Inmueble Rústica de La Comunidad Judía En El Protectorado Español En Marruecos. In Los Judíos En Ceuta, El Norte de África y El Estrecho de Gibraltar. XVI Jornadas de Historia de Ceuta, 125-53. Ceuta: Instituto de Estudios Ceutíes.

Martín Corrales, Eloy. 2013. El Movimiento Obrero En El Protectorado. In Ceuta y El Norte de África Entre Dos Dictaduras (1923-1945): XIV Jornadas de Historia de Ceuta, 177-206. Ceuta: Instituto de Estudios Ceutíes.

Martín Corrales, Eloy. 2013. Tensiones Judeo-Musulmanas En El Protectorado Español En Marruecos En Tiempos de La II República (1931-1936). In Judíos Entre Europa y El Norte de África (Siglos XVI-XXI), 93-118. Barcelona: Bellaterra.

Martín Corrales, Eloy, and Maite Ojeda-Mata. 2016. Spanish Bibliography on the Jews of Morocco. Hespéris-Tamuda LI 2: 103-117.

Mateo Dieste, Josep Lluís. 2003. La "Hermandad” Hispano-Marroquí: Política y Religión Bajo El Protectorado Espanol En Marruecos (1912-1956). Colección Alborán. Barcelona: Edicions Bellaterra.

Moga Romero, Vicente. 2005. Al Oriente de África. Masonería, Guerra Civil y Represión En Melilla (1894-1936). Melilla: Centro Asocciado de la UNED.

Morales Lezcano, Víctor. 1988. Africanismo y Orientalismo Español En El Siglo XIX. Madrid: Universidad Nacional de Educacion a Distancia.

Moreno, Aviad. 2014. Ethnicity in Motion: Social Networks in the Emigration of Jews from Northern Morocco to Venezuela and Israel, 1860-2010.

Moreno, Aviad. 2015. 'Inappropriate' Voices from the Past: Contextualizing Narratives from the First Group Tour of Olim from Northern Morocco to Their Former Hometowns. European Journal of Jewish Studies 9 (1): 52-68.

Moreno, Aviad. 2017. Rethinking Aliyah from Arab and Muslim Countries: The Case of Tangier. AJS Perspectives: The Magazine of the Association for Jewish Studies 2: 24-25. 
Moreno, Aviad. 2020. Beyond the Nation-State: A Network Analysis of Jewish Emigration from Northern Morocco to Israel. International Journal of Middle East Studies 1: 21. https://doi.org/10.1017/ S0020743819000916.

Nicosia, Francis R., and Bogaç A. Ergene. 2018. Introduction. In Nazism, the Holocaust, and the Middle East, 258. New York: Berghahn Books.

Ojeda-Mata, Maite. 2010. Identificacions de Frontera: Glòria i Oblit Dels Jueus de Melilla (1862-1945). Recerques 58 (60): 79-100.

Ojeda-Mata, Maite. 2012. Identidades Ambivalentes Sefardies En La España Contemporánea. Madrid: Sefarad Editores.

Ojeda-Mata, Maite. 2013. Sefardíes En La Masonería Española y Represión Franquista: Barcelona, Melilla y Protectorado de España En Marruecos. In Judios Entre Europa y El Norte de África, 191-210. Barcelona: Bellaterra.

Ojeda-Mata, Maite. 2014. Protección y Naturalización Española de Judíos En El Marruecos Colonial. In Los Judíos En Ceuta, El Norte de África y El Estrecho de Gibraltar. XVI Jornadas de Historia de Ceuta, 277-301. Ceuta: Instituto de Estudios Ceutíes.

Paloma Elbaz, Vanessa. 2016. De Tu Boca a Los Cielos: Jewish Women's Songs in Northern Morocco. Hespéris-Tamuda 51 (3): 239-261.

Paloma Elbaz, Vanessa 2016b. Judeo-Spanish in Morocco. In La Bienvenue et l'adieul1, 103-12. Casablanca: La Croisée des Chemins.

Pinto-abecasis, Nina. 2017. Functionality, Memory and Cultural Anchor: Back to the Haketia Language.

Riaño López, Ana María. 1998. La Communauté Juive de Melilla et Sa Grande Synagogue. Los Muestros 31: 9-10.

Rohr, Isabelle. 2008. The Spanish Right and the Jews, 1898-1945. Brighton and Portland: Sussex Academic Press.

Rohr, Isabelle. 2011. 'Spaniards of the Jewish Type': Philosephardism in the Service of Imperialism in Early Twentieth Century Spanish Morocco". Journal of Spanish Cultural Studies 12 (1): $61-75$.

Rother, Bernd. 2005. Franco y El Holocausto. Historia. Madrid: Marcial Pons.

Salafranca Ortega, Jesús F. 1987. La Presencia Hebrea En Melilla Hasta 1874. Granada: Servicio de Publicaciones de la UNED de Melilla.

Salafranca Ortega, Jesús F. 1995. Historia de La Población Judía de Melilla Desde Su Conquista Por España Hasta 1936. Málaga: Editorial Algazara.

Sánchez Montoya, Francisco. 2004. Ceuta y El Norte de Africa: República, Guerra Civil y Represión, 1931-1944. Nativola: Granada.

Saro Gandarillas, Francisco. 1997. Notas Introductorias. In Melilla La Codiciada, 19-67. Melilla: Ciudad Autónoma de Melilla.

Saro Gandarillas, Francisco. 1997. Notas Introductorias. In La Hija de Marte, 19-73. Melilla: Ciudad Autónoma de Melilla.

Schroeter, Daniel J. 2018. Philo-Sephardism, Anti-Semitism, and Arab Nationalism. In Nazism, the Holocaust, and the Middle East, edited by Francis R Nicosia and Boðaç A Ergene, 1st ed., 179_ 215. Berghahn Books. https://doi.org/10.2307/j.ctvw04fss.13.

Serels, M. Mitchell. 1991. A History of the Jews of Tangier in the Nineteenth and Twentieth Centuries. New York: Sepher-Hermon Press.

Tarrés, Sol. 2013. Los Judíos Ceutíes. In Encuentros: Diversidad Religiosa En Ceuta y Melilla, ed. Rafael Briones, Sol Tarrés, and Óscar. Salguero, 101-122. Barcelona: Icaria.

Tsur, Yaron. 2012. "L'exode de Fès." In La Bienvenue et l'adieu: Migrants Juifs et Musulmans Au Maghreb (XVe-XXe Siècle) II, 9-19. Casablanca: La Croisée des Chemins.

Vilar, Juan B. 1978. "Evolución de la Población Israelita en Marruecos Español (1940-1955)." Estudios Sefardíes 1: 91-120.

Vilar, Juan B. 1985. Tetuán En El Resurgimiento Judío Contemporáneo, 1850-1870: Aproximación a La Historia Del Judaísmo Norteafricano. Caracas: Centro de Estudios Sefardíes de Caracas. 
Vilar, Juan B. 2000. Los Judíos En El Protectorado Español En Marruecos (1940-1956). In Los Judíos En La España Contemporánea: Historia y Visiones, 1898-1998, ed. Uriel Macías Kapón, Yolanda Moreno Koch, and Ricardo Izquierdo Benito, 283-305. Cuenca: Ediciones de la Universidad de Castilla-La Mancha.

Weich-Shahak, Susan. 2008. "Me Vaya a Kapará: La Haketía En El Repertorio Musical Sefardí.” El Presente. Estudios Sobre La Cultura Sefardí 2: 291-300.

Yehuda, Zvi. 1981. The Zionist Organization in Morocco: 1900-1948. Jerusalem: The Hebrew University of Jerusalem.

Publisher's Note Springer Nature remains neutral with regard to jurisdictional claims in published maps and institutional affiliations.

Maite Ojeda-Mata is lecturer at the University of Valencia. Previously she was Marie Skłodowska-Curie European Research Fellow at The Parkes Institute, University of Southampton. She has also been lecturer and researcher in the universities Pompeu Fabra and Autònoma of Barcelona, as well as in the University of Samarkand. She uses a historical anthropological approach on her research to understand sociopolitical processes particularly in the arena of interethnic relations, especially regarding Jewish, Christian, and Muslim relations. She is the author of Modern Spain and the Sephardim: Legitimizing Identities (Lexington Books, 2017) and the co-editor of Judios entre Europa y el norte de África, siglos XV-XXI (Bellaterra, 2013). 